\title{
Implications of Marriage Between Employees of The Same Company Against Work Relationship (Case Study on The Decision of Constitutional Court of The Republic of Indonesia Number 13/PUU-Xv/2017)
}

\begin{abstract}
Ni Komang Arini Styawati and I Ketut Kasta Arya Wijaya
Abstract

Lecturer of Law Faculty, Warmadewa University, Denpasar, Bali, Indonesia

Labor serves a very crucial factor for economic development and growth in each country. Economic growth is one of the most important indicators for the recruitment of workers. Additionally labor is one of the supporting factors in the production process. In employing the workers, employers must pay attention to human rights, for example, companies are not permitted to prohibit their employees from marrying their colleagues in one company because such a prohibition is a violation of human rights. Therefore the Constitutional Court judge had conducted a material test on the provisions of Article 153 paragraph (1) letter $f$ of Law Number 13/2003 concerning Employment, and decided to remove the prohibition on marriage between employees in one company.The consideration of the Constitutional Court Judge to remove the provisions on the prohibition of marriage between employees in one company is because it is not in accordance with the provisions of Article 27 paragraph (2), Article 28 B paragraph (1), Article 28D paragraph (2) of the 1945 Constitution of the Republic of Indonesia, Article 38 paragraph (1) and (2) Law Number 39 Year 1999 concerning Human Rights, and also contradicts the Article 6 paragraph (1) concerning the International Covenant on Economic, Social and Cultural Rights. The decision of the Constitutional Court Judge is a form of legal protection against constitutional rights for workers.
\end{abstract}

Keywords: Marriage, Between Employees, Decision of the Constitutional Court.

DOI: $10.7176 / \mathrm{JLPG} / 87-20$

Publication date:July $31^{\text {st }} 2019$

\section{Introduction}

A national development is carried out for the full development of Indonesian people and the entire Indonesian community to create a prosperous, just, affluent, and evenly distributed society, both materially and spiritually based on Pancasila, the philosophical foundation of the Republic of Indonesia, and the 1945 Constitution of the Republic of Indonesia (or UUDN RI 45). In the implementation of national development, labor has a very important role and position an actor for achieving development goals. In the context of Indonesia, the utilisation of labor is part of efforts to develop human resources directed at increasing the dignity, prestige and ability of the Indonesian people as well as trust in themselves. The deployment of employment development shall based on the consideration that labor development is a comprehensive effort, in all sectors and regions, and is aimed at expanding employment and improving the quality and the work capabilities.

Within a work relationship in one company, sometimes it undeniable that the close relationship between employees with one another (between man and woman) in one office/company will occur and the inner bond of loving each other even to the level of marital relations often takes place. This is a natural respect because the essence of mutual love is the human rights. According to Article 1 of the Law of the Republic of Indonesia Number 1 of 1974 (or the Law No. 1/1974) concerning Marriage, it is stipulated that "Marriage is a physical birth bond between a man and a woman as husband and wife with the aim of forming a contented and eternal family (household) based on the One Godhead." To maintain the survival of the husband and wife and family, each party needs to get decent work for humanity.

In accordance with the role and position of the workforce, the development of labor to improve the quality of labor and participation in development is required as well as increasing the protection of workers and their families in accordance with the dignity and human the dignity also needed. The Indonesian nation has realized that work is a basic need of the citizens to obtain a decent and adequate livelihood for humanity as mandated in Article 27 paragraph (2) of the 1945 Constitution of the Republic of Indonesia, which prescribes: "Every citizen has the right to obtain the work and the livelihood that is appropriate for humanity". From the sound of the article, it is very clearly implied that obtaining the work and a decent livelihood for humanity is the basic right of all citizens without exception. This provision is reaffirmed in Article $28 \mathrm{D}$ paragraph (2), which constitutes an amendment to the 1945 Republic of Indonesia Constitution which stipulates that: "Every person has the right to work and receive compensation and fair and proper treatment in work relations". According to Article 1 number (2) of Law Number 13 of 2003 (Law No.13/2003) concerning Labor, "Employment is anyone 
who is able to carry out the work to produce goods and/or services both to meet their own needs and for the community. Whereas workers/laborers are everyone who works by receiving wages or other forms of rewards (Article 1 number (3) Law No.13/2003).

In consonance with the principle of equality before the law, every Indonesian citizen has the right to choose jobs that are preferred and in accordance with their respective talents, skills and proficiency and is also entitled to fair work conditions and wages and social security of workers. ${ }^{1}$ Government intervention in the field of labor is intended to achieve justice in the field of employment, because if the relationship between workers and employers is left to the parties only (civil), and thus, employers as a stronger party are likely to pressure workers as weaker socio-economic parties. Interference from the government has caused the nature of labor law to be doubled namely private and public. Private is related to the issue of employment agreements between the employers and the workers, while the public nature is the intervention of the government in determining regional or provincial minimum wages.

Employers in hiring workers must pay attention to human rights, or in other words employers are not allowed to forbid their employees to get married with colleagues in one company because the prohibition is a violation of human rights. But in reality there are several companies that make a regulation prohibiting their employees from marrying colleagues who work in one office/company. The powerlessness of the workers in dealing with business actors is clearly detrimental to the workers temselves. In general, business actors take refuge behind a standard contract that has been signed by both the parties (between workers and employers) under the pretext of the principle of freedom of contract, whereas the principle of freedom of contract is limited by law, public order and morality.As for the reason for the prohibition on marital ties between employees in one company, among others are: to maintain the professionalism of employees; so that there is no conflict of interest between husband and wife working in one company; to avoid the element of subjectivity in the application of rules in the company, because if a husband and wife work in the same company, it is feared that the provision of reward and punishment will not be maximized. This has the potential to occur if one of the partners has a higher position and has the authority to do so. So one of the objectives of the ban on marriage between workers from the same company is to avoid Corruption, Collusion and Nepotism. There is a risk of creating the Corruption, Collusion and Nepotism if there is a family relationship in one company/office based on the motives to enrich the family.

The problem is whether the marriage between employees in one company can be used as a basis for terminating employment, and are such restrictions allowed by Indonesian law, given the right to marry is a human right? Then, the right to get a decent job and livelihood is regulated in Article 27 paragraph (2) of the 1945 Indonesian Constitution. From the background above, the issues that are studied in the present study are formulated as follows:

1. What are the legal consequences on the employment relationship of employees who get married with a colleague in one company according to Law Number 13 of 2003 before the Constitutional Court Decision Number 13/PUU-XV/2017?

2. What is the basis for considering the abolition of the provisions of Article 153 paragraph (1) letter (f) of Law Number 13 of 2003 according to Constitutional Court Decision Number 13/PUU$\mathrm{XV} / 2017$ ?

\section{Research Method}

The type of research used for this study is normative legal research, with a statute approach and a case approach. A normative legal research is a research carried out or aimed at the applicable laws and regulations. ${ }^{2}$ The normative legal research is carried out by examining legal materials obtained from primary legal materials, namely the legislation such as: the 1945 Constitution of the Republic of Indonesia, the Law of the Republic of Indonesia No. 39 of 1999 concerning Human Rights; the Law of the Republic of Indonesia No.13 of 2003 concerning Empoyment; the Law of the Republic of Indonesia Number 1 of 1974 concerning Marriage; and the Decision of the Constitutional Court of the Republic of Indonesia Number 13/PUU-XV/2017. Meanwhile, the secondary legal material is collected from the literature relevant to the discussion in this paper. The legal material collection techniques applied is the note-taking technique. Legal materials that have been obtained, then collected, evaluated and compiled systematically, and after that are processed and analyzed by making use of arguments and legal interpretations. Then processing data is presented descriptively, that is, by describing the results of the research. Evaluative techniques encompass the actions taken after describing is

\footnotetext{
${ }^{1}$ Iman Soepomo, 1985, PengantarHukumPerburuhan, CetakanKetujuh, Jambatan, Jakarta, p.53

${ }^{2}$ Bambang Waluyo,2002,Penelitian Hukum Dalam Praktek, Sinar Grafika, Jakarta, p.13
} 
carried out, and is continued by evaluating a legal condition, for example, a law that contradicts other regulations by quoting related articles as they are or a judge's decision. ${ }^{1}$

\section{Results and Discussion}

\subsection{Legal Consequences on the Work Relationship of Employees Who Are Married to Colleagues in One Company According to the Law of the Republic of Indonesia No. 13 of 2003 before the Decision of the Constitutional Court Number 13/PUU-XV/2017}

A work agreement is an agreement between a worker/laborer and an employer that contains the work conditions and the rights and obligations of both of the parties (Article 1 number 14 Law No. 13 of 2003). The work agreement can be made in written form and signed by both parties, and can also be done unwritten/verbally. The work agreements both in writing and verbally shall be made in accordance with the applicable laws and regulations. Employers and employees/workers shall obey the contents of the agreed work agreement. With the existence of a work agreement, a working relationship is formed. The work relationship is the relation between the employers and the workers/laborers based on the work agreements that have the elements of employment, wages and orders. According to Imam Soepomo, an employee relationships is "a relation between the worker/labor and the employer that takes place after an agreement between bothe the parties is held, in which the worker declares his/her ability to work with the employer by receiving wages, and the employer declares his/her ability to employ the worker by paying wages."2

In a work relationship, the position between the employer and the worker/laborer is imbalanced, because the bargaining position is on the employers. The worker/laborer is in a weak position, because as a party that needs the work brings his life to the employer/company. Thus, in making an agreement/work contract that contains the prohibition requirement to marry a colleague in one company, it is generally forced to be signed by the worker/employee even though it contains conditions that are actually not in accordance with their conscience. However, in order to get a job to meet their needs and their family, the employees are forced to sign the employment contract, and the workers must obey the rules of the company where they work, and comply with the contents of the work agreement both in written and oral forms.

The work relations will not last forever because at some point the employment relationship will end. Generally for each worker/laborer, the termination of employment can be a nightmare. Every worker/laborer should make every effort so that he does not lose his job, seeing that the termination of employment can be a beginning of suffering, so the problem of such a situation is always heated among workers and employers, since is can mean an end of income received by workers/laborers regularly.

In the point of fact, the termination of employment is also undesirable for both employers and workers, because after all, employers need the workers to run their companies. However, sometimes companies can suffer losses due to various factors, such as the declining of the purchasing power, even if the company is on the verge of bankruptcy, resulting in a forced termination of employment. However, whether or not a termination of employment is something that is very possible and reasonable occurs in the context of a work relationship. The work relationship between the workers and employers, sooner or later, will eventually end, so that there is no work relationship that lasts eternally. However, the event of the termination of employment often gives rise to complex problems, both regarding the termination of employment and the legal consequences of the termination of employment (related to severance issues). For example, a termination of employment may occur as a result of marriage between employees in one company.

If a company regulates the prohibition for workers to marry colleagues in one company, of course when there are employees who get married with their colleagues in one office/ company, one of the partners is usually recommended to resign from the company where they work. Thus, the termination of the employment against the employee is occurring. So, the employee will automatically lose his/her job. The legal basis made by the company to make such a rule is the provision of Article 153 paragraph (1) letter (f) of Law Number 13/2003 concerning the Employment determining that "employers are prohibited from terminating employment on the grounds that the workers have blood ties and/or marital ties with other workers/laborers in one company, except as stipulated in the work agreements, company regulations, or collective labor agreements".

If examined from the sound of the Article 153 paragraph (1) letter (f) mentioned above, the phrase "... except as stipulated in the work agreements, company regulations, or collective labor agreements". This

${ }^{1}$ I Made Pasek Diantha, 2017, Metodologi Penelitian Hukum Normatif Dalam Justifikasi Teori Hukum, 2nd Edition,Prenada Media Group, Jakarta, p. 152

${ }^{2}$ Maimun, 2004. Hukum Ketenagakerjaan Suatu Pengantar, Cetakan I, Jakarta: PT. PradnyaParamita, p.37 
provision provides opportunities or gaps for the companies to be used as a basis of making the regulations that prohibit the employees/workers from marrying colleagues in one company. In other words, the Article 153 paragraph (1) letter (f) of Law Number 13 of 2003 allows each company to terminate the worker on the grounds that they get married with their colleagues in one company, insofar as it has been regulated in a work agreement or in a company regulations, or an agreement joint work (this provision applies before the Constitutional Court Decision No. 13/PUU-XV/2017).

\subsection{The Basis of Considerations for the Abolition of the Provisions of Article 153 paragraph (1) letter (f) of Law Number 13 of 2003 concerning Employment in Accordance with to the Constitutional Court Decision Number 13/PUU-XV/2017}

Everyone has the right to form a family and to continue their descent through legal marriage. Likewise, every citizen has the right to obtain the work and a decent living for humanity. Therefore, prohibiting the employees from marry their colleagues in one company and threatening them by terminating their employment because of the reason they have been married to a colleague in one company is an act that violates the Human Rights. This is also contrary to the 1945 Constitution of the Republic of Indonesia.

In the provisions of Article 153 paragraph (1) letter (f) Law No. 13 of 2003 stated, is stipulated that: "Employers are prohibited from terminating their employees on the grounds that they have blood ties and/or marital ties with other workers/laborers in same company, unless stipulated in a work agreement, company regulations, or collective labor agreement". In practice, the phrase in Article 153 paragraph (1) letter f of Law No. 13 of 2003, “... except as stipulated in work agreement, company regulation, or collective labor agreement”, is used as a basis by the company to prohibit employees/workers from marrying their colleagues from the same company. If the worker/laborer still wants to marry his/her colleague the same company, usually the company requires one of the employees to resign from the company. ${ }^{1} \mathrm{Hal}$ initentumerugikanbagipihakkaryawan/pekerja.

There is one case example. A group of employees who found that their constitutional rights (the rights referred to as in the 1945 Constitution of the Republic of Indonesia) were harmed, finally submitted a petition for judicial review of the provisions of Article 153 paragraph (1) letter (f) Law Number 13 Year 2003 to the Constitutional Court of the Republic of Indonesia. They considered these provisions to be very detrimental to the workers or laborers, due to the loss of guarantees of decent work and livelihood for the workers or laborers. The petition was submitted by 8 (eight) employees of PT. PLN (State Electricity Company), namely: Jhoni Boetja, Edy Supriyanto Saputro, Airtas Asnawi, Syaiful, Amidi Susanto, Taufan, MuhamadYunus, and YektiKurniasih. ${ }^{2}$ The claim was submitted to the Constitutional Court in the file number 13/PUU-XV/2017. The eight employees questioned the article governing the "prohibition on marriage between employees/workers in the same company". The object of the petition is the material test of Article 153 paragraph (1) letter (f) of Law Number 13 of 2003 concerning the Employment.

The legal basis regarding the authority of the Constitutional Court to test the legislation is:

1. Article 24 C paragraph (1) of the 1945 Constitution of the Republic of Indonesia prescribes that one of the authorities of the Constitutional Court is to examine the legislation against the 1945 Constitution of the Republic of Indonesia.

2. Article 10 paragraph (1) letter a of the Law Number 8 Year 2011 concerning the Amendment to the Law Number 24 of 2003 concerning the the Constitutional Court specifies that: "The Constitutional Court has the authority to try at the first and last level whose decision is final to test the law against the 1945 Constitution of the Republic of Indonesia".

3. Article 12 paragraph (1) letter a ofthe Law Number 4 of 2004 concerning Judicial Power states:

"The Constitutional Court has the authority to adjudicate at the first and final level, whose decisions are final in order to examine the laws against the 1945 Constitution of the Republic of Indonesia".

The Legal standing for the applicants in submitting a quo petition is as follows:

1. Based on Article 28 C paragraph (2) of the 1945 Constitution of the Republic of Indonesia:

"Everyone is entitled to advance themselves in fighting for their rights collectively to build their community, nation and country".

2. Based on Article 28 D paragraph (1) of the 1945 Constitution of the Republic of Indonesia:

"Everyone is entitled to the recognition, guarantee, protection and fair legal certainty and equal treatment before the law".

3. Based on Article 51 paragraph (1) of the Law on the Constitutional Court:

${ }^{1}$ Kristian Erdianto, 2017, MK Hapus Aturan yang Larang Pernikahan Antar-karyawan Sekantor, Kompas.com, Kamis, 14 Desember 2017, https://www.google.com., Accessed June 6, 2019

${ }^{2}$ Kristian Erdianto, 2017, MK Hapus Aturan yang Larang Pernikahan Antar-karyawanSekantor, KOMPAS.com, Kamis, 14 Desember 2017, https://www.google.com, Accessed June 6, 2019 
"The Petitioners are the party who considers his constitutional rights and/or authorities aggrieved by the coming into the effects of the Law, namely: a) the Indonesian citizen, b) the customary law community units as long as they are still liwing and in accordance with the development of the people and principles of the Unitary State of the Republic of Indonesia regulated in law, c) the public and private legal entities, or d) state institutions".

The norm that can be petitioned for review is the Article 153 paragraph (1) letter (f), which states that "Employers are prohibited from terminating the employment on the grounds: "The workers/laborers have the blood ties and/or marital ties with other workers/laborers in one company, unless it has been regulated in a work agreement, company regulation or collective labor agreement".

The norms of the 1945 Constitution of the Republic of Indonesia relating to the aforementioned cases are:

1. Article 27 paragraph (2): "Every citizen has the right to decent work and livelihood for humanity".

2. Article $28 \mathrm{~B}$ paragraph (1): "Every person has the right to form a family and to continue their descents through a legal marriage”.

3. Article $28 \mathrm{C}$ paragraph (1): "Everyone has the right to develop themselves through meeting their basic needs, having the right to get education and to benefit from science and technology, art and culture, to improve their quality of life and for the welfare of humanity".

4. Article 28 D paragraph (1): "Every person has the right to recognition, guarantee, protection, and fair legal certainty and equal treatment before the law."

5. Article $28 \mathrm{D}$ paragraph (2): "Every person has the right to work and receive compensation and fair treatment in the proper working relationship".

6. Article 28 I paragraph (2): "Every person has the right to be free from treatment that is discriminatory on any basis and has the right to receive protection against such discriminatory treatment".

The reasons for the lawsuit filed with the Constitutional Court are:

1. That the petitioners are harmed due to the enactment of the a quo provisions, because the petitioners will lose their jobs due to the marriage with their colleagues in one company in case it is regulated in a work agreement, company regulation or collective labor agreement;

2. Article 153 paragraph (1) letter (f) of Law No.13/2003 concerning Prohibition is contrary to Article 27 paragraph (2), Article 28 B paragraph (1), Article 28 C paragraph (1), Article 28 D paragraph ( 1) and (2), Article 28 I paragraph (2) of the 1945 Constitution of the Republic of Indonesia for limiting the human rights;

3. This marriage restriction with fellow employees in one company can be used arbitrarily by interested parties to terminate the employment.

Petition sued by the petitioner:

1. To consent the petition of the petitioner;

2. To declare that the partial cancellation of provisions of the Article 153 paragraph (1) letter (f) of the Law Number 13 of 2003 concerning the Employment which reads "unless it has been stipulated in a work agreement, company regulation or collective labor agreement" is contrary to the 1945 Constitution of the Republic of Indonesia and to declare that it has no binding legal force ever since it was decided by the Constitutional Court;

3. To order the imposition of this decision in the State Gazette of the Republic of Indonesia.

Therefore, the petitioner claims the Constitutional Court to cancel the phrase in Article 153 paragraph (1) letter (f) of Law No.13/2003 so that the company cannot terminate the employment only on the grounds of marriage with fellow workers in the same company. With the cancellation of the phrase "... unless it has been stipulated in a work agreement, company regulation, or collective labor agreement" stipulated in the Article 153 paragraph (1) letter (f) of Law No.13 / 2003, the workers' constitutional rights are protected, Jhoni said in his request. The petitioners explained the reason for filing the lawsuit to the Constitutional Court representing the petitioners. Jhoni said that marriage is a religious order. Moreover the marriage mate cannot be challenged because the marriage bond between a man and a woman who has a sense of mutual love is difficult to resist. ${ }^{1}$

The Constitutional Court Judge stated that a company cannot make the marriage bond between workers or laborers in one company a reason to terminate the employment. In his consideration, the Constitutional Court stated that the blood ties or marriage are destiny, things that cannot be avoided. In addition, with the existence of 
marriage there is no right of others who are disturbed. Then the Constitutional Court also stated that the companies which requires workers or laborers not to have blood ties or marriages with workers in one company and make it the reason for termination of employment are making the provisions that are not in line or contrary to the norms in Article 27 paragraph (2) of the 1945 Constitution of the Republic of Indonesia, which reads "Every citizen has the right to work and a decent life for humanity. Article 28 B paragraph (1) determines that "Everyone has the right to form a family and to continue the descent through a legal marriage. Article 28D paragraph (2) of the 1945 Constitution of the Republic of Indonesia specifies, "Every person has the right to work and receive compensation and fair and proper treatment in the work relationship". Article 38 paragraph (1) and (2) Law No. 39/1999 concerning Human Rights regulates: 1) everyone has the right according to their talents, skills and abilities entitled to decent work; 2) everyone has the right to freely choose the job he/she prefers and has the right to employment conditions.In Article 6 paragraph (1) of the International Covenant on Economic, Social and Cultural Rights, it is determined that "Every human being has the right to the right to life inherent in him. This right must be protected by law. No one's life rights can be arbitrarily seized". Judge Aswanto said that the blood ties or marital relations are inevitable fate. Therefore making something destined as a condition to override the fulfillment of human rights, in this case the right to work and the right to form a family, cannot be accepted as a legitimate reason constitutionally. With the decision of the Constitutional Court, a company cannot set rules that prohibit employees from marrying their colleagues in one company. The Constitutional Court Judge stated that marriage between office employees cannot be used as a basis for terminating the employment.

\section{Conclusion}

1. Before the Constitutional Court Decision Number 13/PUU-XV/2017 is issued, marriage between employees in one company can be used as the basis for terminating employment based on Article 153 paragraph (1) letter (f) of Law Number 13 of 2003 concerning Employment.

2.After the Constitutional Court Decision Number 13/PUU-XV/2017 is issued, the marriage between employees in one company cannot be used as a basis for terminating employment. The basic consideration of the Constitutional Court Judge to remove the provisions of the prohibition on marriage between employees in one company is because it violates the human rights and is contrary to the provisions of Article 27 paragraph (2), Article 28 B paragraph (1), Article 28D paragraph (2) of the 1945 Constitution of the Republic of Indonesia, Article 38 paragraph (1) and (2) Law No. 39/1999 concerning Human Rights, and is contrary to Article 6 paragraph (1) of the International Covenant on Economic, Social, and Cultural Rights.

\section{Recommendation}

1. For the government, there should be amandment immediately made to the provisions of Article 153 paragraph (1) letter (f) of Law Number 13 of 2003 concerning Employment, because it is not in accordance with the 1945 Constitution of the Republic of Indonesia, Law No. 39/1999 concerning Human Rights, and the International Covenant on Economic, Social and Cultural Rights, as has been decided by the Constitutional Court.

2. For employers, in making company rules concerning labor, in addition to referring to the applicable laws and regulations, it is also expected to pay attention to the human rights.

3. For workers, it is expected to be able to improve the quality of themselves as human resources so that they can compete to penetrate the labor market.

\section{REFERENCES}

I Made Pasek Diantha, 2017, Metodologi Penelitian Hukum Normatif Dalam Justifikasi TeoriHukum, $\quad$ 2nd Edition, Prenada Media Group, Jakarta.

Edy Sutrisno Sidabutar, 2007. Pedoman Penyelesaian PHK, 1st Edition, $\quad$ Tangerang:Elpress.

Iman Soepomo, 1985, Pengantar HukumPerburuhan, 7th Edition, Jambatan, Jakarta.

Lalu Husni, 2003. Pengantar Hukum Ketenagakerjaan Indonesia,3rd Edition, Jakarta: PT. Raja Grafindo Persada.

Libertus Jehani, 2008. Hak-hak Karyawan Kontrak, 1st Edition, Jakarta, Forum Sahabat. Maimun, 2004. Hukum Ketenagakerjaan Suatu Pengantar, 1 Edition, Jakarta: PT. Pradnya Paramita. 1945 Constitution of the Republic of Indonesia 
Law Number 13 of 2003 concerning Employment

Law Number 39 of 1999 concerning Human Rights

Decision of the Constitutional Court Number 13/PUU-XV/2017

Kristian Erdianto, 2017, MK HapusAturan yang LarangPernikahanAntar-karyawanSekantor, KOMPAS.com, https://www.google.com, Accessed June 6, 2019 